\title{
TEMPERATURE AND HOST DEPENDENT FUNCTIONAL RESPONSE OF ANISOPTEROMALUS CALANDRAE (HOW.) AND CHOETOSPILA ELEGANS (WESTW.) PARASITODS IN PARASITIZING WHEAT INFESTING RHYZOPERTHA DOMINICA (F.) (COLEOPTERA: BOSTRICHIDAE)
}

\author{
M. M. Rahman and W. Islam* \\ Institute of Biological Sciences, Rajshahi University, Rajshahi, Bangladesh
}

\begin{abstract}
Rhizopertha dominica (F.) (Coleoptera: Bostrichidae) is an internal feeder of whole wheat seed, flour, etc. R. dominica is parasitized by two pteromalid ectoparasitoids, Anisoptetromalus calandrae (How.) and Choetospila elegans (Westw.) in the larval and pupal stages. The effects of host density and temperature on the functional response of the parasitoids in parasitizing the larval and pupal stages of the hosts were examined. Four temperatures and five host densities were used. A functional response equation was used in which a quadratic component that included temperature was substituted for handling time. Functional response of parasitization by A. calandrae and C. elegans fit a formula of Hassell et al. (1977) type III model. The maximum rate of parasitization of $A$. calandrae was 8.6 larvae/24 hrs and 7.2 larvae/24 hrs of C. elegans at $30^{\circ} \mathrm{C}$, respectively. Handling time and instantaneous search rate varied with temperatures. The ability of $A$. calandrae and $C$. elegans to find and parasitize $R$. dominica over a broad range of temperatures demonstrate it as a good candidate for natural control of the pest.
\end{abstract}

Key words: Anisopteromalus calandrae, Choetospila elegans, functional response, lesser grain borer, Rhyzopertha dominica

\section{INTRODUCTION}

The lesser grain borer, Rhizopertha dominica (F.) an internal feeder is one of the most abundant pests of wheat, stored cereals and grains (Potter 1935, Alam 1971). The species virtually feeds on all kinds of stored grain and milled cereals causing severe damage of the stored commodities throughout the world (Chittenden 1911, Edde 2012), and especially in the tropical and subtropical countries (Dhaliwal 1976) including Bangladesh (Alam 1971, Hossain et al. 1986). The damage is caused by larval and adult stages (Cotton 1963, Cambell and Sinha 1976). This pest is with high fecundity, polyphagous in nature, and also shows quick resistance against insecticides so consequently the control of this pest for a long time is quite difficult. Anisopteromalus calandrae (How.) and Choetospila elegans (Westw.) are the larval and pupal ectoparasitoids of $R$. dominica belonging to the family Pteromalidae (Islam 1993, Biswas et al. 2004). These parasitoids are present in the natural conditions and at certain time of the year they considerably check the population in the granaries or

*Author for correspondence: <mwislam18@gmail.com>

(C) 2018 Zoological Society of Bangladesh DOI: https://doi.org/10.3329/bjz.v47i1.42019 
stores infested by $R$. dominica. The mated female of $A$. calandrae and $C$. elegans deposited their eggs on the external surface of the host body by inserting the ovipositor through the outer seed-coat of the infested grains separately. The newly hatched larvae suck the body fluids of the host continuously for development, pass through different life-stages and ultimately emerge as adults by causing death of the host insects. The parasitoid takes 10 - 12 days to complete their entire life cycle from egg to adult emergence in case of $A$. calandrae but 16 - 18 days in case of C. elegans (Islam 1993, Biswas et al. 2004). Host-feeding is generally regarded as a normal process in Ptreomalidae (Clausen 1962). Both the parasitoids forms feeding tube extending from the surface of the body of the host insect to outside the seed and feeds on the host's fluid that oozes through the feeding tube.

The rate at which parasitoids attack hosts is dependent on host density. This relationship has been described as a functional response to host density (Solomon 1949). Temperature also affects functional response and general models have been developed (Flinn 1991). Parasitoid life-history characteristics change as a function of temperature (Smith 1994). Searching and attack rates are also expected to be affected by temperature (Flinn 1991), and it is possible that handling time is also affected. A good number of reports are available on the effects of temperature on functional response (Messenger 1968, Flinn 1991) and only Mack et al. (1981) proposed a general eight-parameter equation. However, the shape and height of the curve vary among species and foraging conditions. Thus, to build a predictive model, a study on the particular parasitoid, host, and environment of interest must be conducted. In the present study a temperature-mediated functional response equation that uses a quadratic function for handling time. This model is used to predict attack rate as a function of host density and temperature.

\section{MATERIAL AND METHODS}

Adult Rhizopertha dominica and its parasitoids, Anisopteromalus calandrae and Choetospila elegans used in this research were obtained from cultures maintained in control temperature (CT) room $\left(30 \pm 0.5^{\circ} \mathrm{C}\right.$ and $\left.70 \% \mathrm{RH}\right)$ at Entomology and Insect Biotechnology Laboratory, Institute of Biological Sciences, University of Rajshahi since last ten years. One to two day-old eggs of $R$. dominica were obtained by allowing adults to oviposit in wheat and then the beetles were separated from the wheat to recover the eggs. The wheat kernels were infested with $R$. dominica larvae by using a needle to make a small hole in the kernel and placing one $R$. dominica egg on it. The kernels were placed into the individual vials and held at CT room for 21 days to allow them to develop into the $4^{\text {th }}$ instar larvae. The wheat kernels were infested with $R$. dominica larvae. Different infested kernels 2, 4, 8, 16 and 32 were mixed into $300 \mathrm{gm}$ 
wheat (12\% moisture content, wet weight) and kept in glass jars (7 cm diam, $13.5 \mathrm{~cm}$ length).

After mating, the mated females of $A$. calandrae and C. elegans were released in to the jars separately. After emergence, the number of adult parasitoids was recorded. The experiment was carried out at four different temperatures viz., 20, 25, 30 and $35^{\circ} \mathrm{C}$ and $70 \pm 0.5 \%$ RH. Each treatment was replicated five times.

The type III response is the most common for insect predators and parasitoids. Here type I and type II models of Holling's (1959a,b) and type III model of Hassell et al. (1977) are used following the formula given below:

$\begin{array}{lll}\text { Type I: } & \mathrm{N}_{\mathrm{A}}=\mathrm{aTN} & 1 \\ \text { Type II: } & \mathrm{N}_{\mathrm{A}}=\mathrm{aTN} /\left(1+\mathrm{aT}_{\mathrm{h}} \mathrm{N}\right) & 2 \\ \text { Type III: } & \mathrm{N}_{\mathrm{A}}=\mathrm{N}\left[1-\exp \left\{-\mathrm{a}\left(\mathrm{T}-\mathrm{T}_{\mathrm{h}} \mathrm{N}_{\mathrm{a}}\right)\right\}\right] & 3\end{array}$

In these models, $\mathrm{N}_{\mathrm{A}}$ is the number of host parasitized, $\mathrm{N}$ is the initial density of parasitoids, $\mathrm{T}$ is the time available for searching during the experiment, $\mathrm{a}$ is the instantaneous rate of discovery and $T_{h}$ is the amount of handling time per host. The coefficient of determination ( $\mathrm{r}^{2}$ values) were calculated by SAS PROCNLIN (SAS Institute 1996). Parameters a and $\mathrm{T}_{\mathrm{h}}$ from the functional response models were estimated using SAS PROCNLIN methods (SAS Institute 1996) also. All analyses of density effects on predations and comparisons of predation relating to male and female were completed using SAS PROC MIXED method (SAS Institute 1996).

\section{RESULTS AND DISCUSSION}

The different temperatures were fit separately in equation III model (Table 1). In $A$. calandrae, the parasitization rate increased with host density at all temperatures tested. Handling time was highest at $20^{\circ} \mathrm{C}$ but lowest at $30^{\circ} \mathrm{C}$, respectively. Instantaneous search rates were $0.015 \pm 0.008,0.061 \pm 0.16,0.112 \pm 0.045$ and $0.451 \pm 0.110$ at $20,25,30$ and $35^{\circ} \mathrm{C}$, respectively. The coefficients of determination $\left(\mathrm{r}^{2}\right.$ values) were $0.9890,0.9959,0.9936$ and 0.9636 on the above mentioned temperatures. The instantaneous search rates were highest at $35^{\circ} \mathrm{C}$ and lowest at $20^{\circ} \mathrm{C}$. The maximum parasitization rates were $1.80,4.40,8.60$ and 7.90 at $20,25,30$ and $35^{\circ} \mathrm{C}$, respectively. It was highest (8.6) at $30^{\circ} \mathrm{C}$ but lowest (1.8) at $20^{\circ} \mathrm{C}$. Analysis of variance shows that production of $\mathrm{F}_{1}$ progeny of $A$. calandrae on $R$. dominica was significantly $(\mathrm{p}>0.01)$ different in different parasitoid densities and temperatures.

In case of $C$. elegans, handling times were $20 \pm 3.10,5.68 \pm 0.62,3.37 \pm 0.18$ and $4.90 \pm 0.37$ at $20,25,30$ and $35^{\circ} \mathrm{C}$, respectively (Table 2). Instantaneous search rates 
were $0.020 \pm 0.006,0.056 \pm 0.021,0.125 \pm 0.035$ and $0.501 \pm 0.120$ on the same temperatures but highest at $35^{\circ} \mathrm{C}$ and lowest at $20^{\circ} \mathrm{C}$. The coefficients of the determination ( $\mathrm{r}^{2}$ values) were $0.3124,0.9974,0.9783$ and 0.9978 and the maximum number of parasitized were $0.8,4.4,7.2$ and 4.8 at $20,25,30$ and $35^{\circ} \mathrm{C}$, respectively. The maximum parasitized was highest at $30^{\circ} \mathrm{C}$ and lowest at $20^{\circ} \mathrm{C}$. Analysis of variance shows that production of $\mathrm{F}_{1}$ progeny of $C$. elegans on $R$. dominica was significantly $(\mathrm{p}>0.01)$ different in different parasitoids densities and temperatures.

Table 1. Estimates of handling time $\left(T_{h}\right)$, instantaneous search rate (a), coefficient of determination ( $r^{2}$ values) and maximum number of parasitized by $A$. calandrae on $R$. dominica

\begin{tabular}{ccccc}
\hline $\begin{array}{c}\text { Temperature } \\
\left({ }^{\circ} \mathrm{C}\right)\end{array}$ & $\begin{array}{c}\text { Handling time } \\
\left(\mathrm{T}_{\mathrm{h}}\right) \pm \mathrm{SE}(\mathrm{h})\end{array}$ & $\begin{array}{c}\text { Instantaneous } \\
\text { search rate }(\mathrm{a}) \pm \mathrm{SE}\end{array}$ & $\begin{array}{c}\mathrm{r}^{2} \text { values for } \\
\text { type-III }\end{array}$ & $\begin{array}{c}\text { Max. no. } \\
\text { parasitized }\end{array}$ \\
\hline 20 & $16.15 \pm 3.35$ & $0.015 \pm 0.008$ & 0.9890 & 1.8 \\
25 & $6.25 \pm 0.73$ & $0.061 \pm 0.016$ & 0.9959 & 4.4 \\
30 & $2.85 \pm 0.21$ & $0.112 \pm 0.045$ & 0.9936 & 8.6 \\
35 & $3.16 \pm 0.26$ & $0.451 \pm 0.110$ & 0.9636 & 7.8 \\
\hline
\end{tabular}

Table 2. Estimates of handling time (Th), instantaneous search rate (a), coefficient of determination ( $r^{2}$ values) and maximum number of parasitized by $C$. elegans on $R$. dominica

\begin{tabular}{clccc}
\hline $\begin{array}{c}\text { Temperature } \\
\left({ }^{\circ} \mathrm{C}\right)\end{array}$ & $\begin{array}{c}\text { Handling time } \\
(\mathrm{Th}) \pm \mathrm{SE}(\mathrm{h})\end{array}$ & $\begin{array}{c}\text { Instantaneous } \\
\text { search rate }(a) \pm \mathrm{SE}\end{array}$ & $\begin{array}{c}\mathrm{r}^{2} \text { values for } \\
\text { type-III }\end{array}$ & $\begin{array}{c}\text { Max. No. } \\
\text { parasitized }\end{array}$ \\
\hline 20 & $20 \pm 3.10$ & $0.020 \pm 0.006$ & 0.3124 & 0.8 \\
25 & $5.68 \pm 0.62$ & $0.056 \pm 0.021$ & 0.9974 & 4.4 \\
30 & $3.37 \pm 0.18$ & $0.125 \pm 0.035$ & 0.9783 & 7.2 \\
35 & $4.90 \pm 0.37$ & $0.501 \pm 0.120$ & 0.9978 & 4.8 \\
\hline
\end{tabular}

The efficacy of both the parasitoids were found to increase with increasing temperatures. A short handling time increases the time available for searching and hence the likelihood of finding additional hosts. The estimated handling time was lowest at $30^{\circ} \mathrm{C}$ but highest at $20^{\circ} \mathrm{C}$ in the present findings. Table 3 shows the equation fitted $A$. calandrae and $C$. elegans on $R$. dominica to each temperature. The rate of parasitization was more variable at 30 and $35^{\circ} \mathrm{C}$ than at 20 and $25^{\circ} \mathrm{C}$. Thirty degree centigrade is the suitable temperature for parasitization than others one. In every case, A. calnadrae is better than C. elegans for parasitization.

In the present result handling time and search rate varied in response to temperature. Both handling time and instantaneous search rate were correlated over the range of temperatures examined. Thus, by making handling time a function of temperature, instantaneous search rate was also adjusted. In control, instantaneous search rate primarily affects the shape of the functional response at low to intermediate host densities. 
Mack et al. (1981) developed a temperature-mediated functional response and found that the relationship between handling time and temperature should be U-shaped because there should exist an optimum and two temperature extremes at which handling time is infinite. The present results are similar to that of Mack et al. (1981).

Table 3. Functional response of $A$. calandrae and $C$. elegans parasitizing $R$. dominica at different temperatures

\begin{tabular}{|c|c|c|c|c|c|c|c|c|}
\hline \multirow{2}{*}{$\begin{array}{l}\text { Den- } \\
\text { sity }\end{array}$} & \multicolumn{4}{|c|}{ A. calandrae $\left({ }^{\circ} \mathrm{C}\right)$} & \multicolumn{4}{|c|}{ C. elegans $\left({ }^{\circ} \mathrm{C}\right)$} \\
\hline & 20 & 25 & 30 & 35 & 20 & 25 & 30 & 35 \\
\hline \multirow[t]{2}{*}{2} & 0.2 & 0.40 & 0.60 & 0.60 & 0 & 0.60 & 0.80 & 0.60 \\
\hline & \pm 0.20 & \pm 0.24 & \pm 0.24 & \pm 0.24 & & \pm 0.24 & \pm 0.37 & \pm 0.24 \\
\hline \multirow{2}{*}{4} & 0.60 & 1.00 & 1.60 & 1.00 & 0 & 0.80 & 1.20 & 1.20 \\
\hline & \pm 0.24 & \pm 0.31 & \pm 0.40 & \pm 0.31 & & \pm 0.37 & \pm 0.37 & \pm 0.37 \\
\hline \multirow{2}{*}{8} & 1.05 & 2.20 & 3.80 & 3.40 & 0.4 & 1.60 & 3.20 & 1.60 \\
\hline & \pm 0.31 & \pm 0.37 & \pm 0.37 & \pm 0.51 & \pm 0.24 & \pm 0.51 & \pm 0.37 & \pm 0.51 \\
\hline \multirow{2}{*}{16} & 1.40 & 2.60 & 4.80 & 4.80 & 0.6 & 2.80 & 4.80 & 2.80 \\
\hline & \pm 0.51 & \pm 0.51 & \pm 0.08 & \pm 0.37 & \pm 0.24 & \pm 0.48 & \pm 0.37 & \pm 0.37 \\
\hline \multirow{2}{*}{32} & 1.80 & 4.40 & 8.60 & 7.80 & 0.8 & 4.40 & 6.80 & 4.80 \\
\hline & \pm 0.37 & \pm 0.51 & \pm 0.67 & \pm 0.60 & \pm 0.37 & \pm 0.40 & \pm 0.58 & \pm 0.37 \\
\hline
\end{tabular}

Present results suggest that both $A$. calandrae and $C$. elegans could be effective in reducing populations of $R$. dominica in stored wheat. They are able to attack up to 8.6 larvae and 7.2 larvae per $12 \mathrm{hrs}$. This is relatively high rate of attack compared with other stored-grain parasitoids. The above mentioned parasitoids have been found throughout the stored wheat grain mass in stores. Thus, parasitoids should be able to parasitize hosts that are located in any region of the wheat grain mass. The parasitoids also attacked $R$. dominica over more or less all full range of temperatures that are optimal for its growth.

Host feeding is an important mortality factor that would need to be included in a model for $R$. dominica. Host feeding is a desirable character for biological control agents because it does not only depress host density but also has a stabilizing effect on the system (Yamamura and Yano 1988). Hosts that are parasitized but are not killed by host feeding may provide additional stability to the system. In the present study parasitized hosts larvae do not progress to the next developmental stage ultimately the hosts die due to host feeding.

A. calandrae and C. elegans are the best candidates for biological control of the lesser grain borer. The changes of parasitoid for finding suitable host may be much greater than for other developing inside the grain kernel. Both the parasitoids increases host mortality by parasitizing and feeding on 2nd to all life stages of $R$. dominica. The generation times are half than that of their host and 
they are very host-specific. Searching efficiency is usually higher in host-specific parasitoids (Hassell 1978) and can lead to a greater depression of host equilibrium.

The ability of $A$. calandae and $C$. elegans to find and parasitize $R$. dominica over a broad range of temperatures make them good candidates for natural control of stored grain pests where temperature fluctuations are frequent. Expert systems already exit for pest management in stored grain (Flinn and Hagstrum 1990). A. calandrae and C. elegans are two efficient parasitoids of $R$. dominica in stores that could be used for biological control agents. The experiments conducted in this study have demonstrated that the effectiveness of the parasitoids depend on the prevailing temperatures in different storages.

\section{LITERATURE CITED}

ALAM, M.Z. 1971. Pests of stored grains and other stored products and their control. Agricuture Information Service, Dhaka, Bangladesh. pp. 7-10.

BISWAS, L., ISLAM, W. and MONDAL, K.A.M.S.H. 2004. Potentiality of the parasitoids, Anisopteromalus calandrae (How.) and Choetospila elegans Westwood for the control of Sitophilus oryzae L. J. Biological Control 18:141-145

CAMPBELL, A. and SINHA, R.N. 1976. Damage of wheat by feeding of some stored product beetles. J. Econ. Entomol. 69: 11-13

CHITTENDEN, F.H. 1911. The lesser grain borer and the larger grain borer. Bull. United State Bureau Entomol. 96: 29-47.

CLAUSEN C.P. 1962. Entomophagus insects. Hubner Publ. Co., New York. pp. 688.

COTTON, R.T. 1963. Pests of stored grain and grain products. Burgess Co. pp. 333.

DHALIWAL, G.S. 1976. Intensity of insect infestation under rural storage conditions in Punjab. Entomologist Newsletter 6: 40-50.

EDDE, P.A. 2012. A review of the biology and control of the lesser grain borer, Rhyzopertha dominica. J. Stored Prod. Res. 48: 1-8

FLINN, P.W. 1991. Temperature-dependent functional response of the parasitoid Cephalonomia waterstoni (Gahan) (Hymenoptera: Bethylidae) attacking rusty grain beetle larvae (Coleoptera : Cucujidae). Environ. Entomol. 20: 872-876.

FLINN, P.W. and HAGSTRUM, D.W. 1990. Simulations comparing the effectiveness of various storedgrain management practices used to control Rhizopertha dominica (Coleoptera: Bostrichidae). Envion. Entomol. 19: 393-402.

HASSELL, M.P. 1978. The dynamics of Arthropod Predator Systems. Princeton Uni. Press, Princeton, NJ.

HASSEL M.P., LAWTON, J.H. and BEDDINGTON, J.R. 1977. Sigmoid functional response by invertebrate predators and parasitoids. J. Anim. Ecol. 46: 249-262.

HOLLING, C.S. 1959a. The components of predation as revealed by a study of small-mammal predation of the European pine sawfly. Can. Entomol. 91: 293-320.

HOLLING, C.S. 1959b. Some characteristics of simple types of predation and parasitism. Can. Entomol. 91: 358-398.

HOSSAIN, M., VERNER, P.H. and REZAUR, R. 1986. Taxonomic descriptions of the mature larvae of six species of Crytolestes (Coleoptera: Cucujidae). Bangladesh J. Zool. 14: 139-148. 
ISLAM, W. 1993. The biology of Anisopteromalus calandrae How. - ectoparasitoid on Callosobruchus chinensis L. Bangladesh J. Zool. 21: 123-132.

MACK, T.P., BAJUSZ, B.A., NOLAN, E.S. and SMILOWITZ, Z. 1981. Development of a temperaturemediated functional response equation. Environ. Entomol. 10: 573-579.

MESSENGER, P.S. 1968. Bioclimatic studies of the aphid parasite Praon exsoletum. Can. Entomol. 100: $728-741$.

POTTER, C. 1935. The biology and distribution of Rhizopertha dominica F. Transsactions Royal Entomol. Soc., London 83: 449-482.

SAS INSTITUTE 1996. SAS/STAT user's guide for personal computers. Version 6.12 ed. SAS Institute, Cary, NC.

SOLOMON, M.E. 1949. The natural control of animal populations. J. Anim. Ecol. 18: 1-35.

SMITH, L. 1994. Temperature influences functional response of Anisopteromalus calandrae parasitizing maize weevil larvae in shell corn. Ann. Ent. Soc. Am. 87: 849-855.

Yamamura, N. and Yano, E. 1988. A simple model of host-parasitoid interaction with host-feeding. Res. Popul. Ecol. 30: 353-369.

(Manuscript received on 22 December 2018; revised on 8 May, 2019) 